\title{
SOSIAALITYÖN ASIANTUNTIJUUS VASTAANOTTOPALVELUISSA
}

\author{
Eeva Elfving: YTM, tohtorikoulutettava, Jyväskylän yliopisto, Kokkolan yliopistokeskus Chydenius \\ Sari Kärkkäinen: $Y T M$ \\ eeva.elfving@gmail.com; sari.kark.kainen@gmail.com
}

Janus vol. 26 (4) 2018, 361-369

\section{JOHDANTO}

Tässä puheenvuorossa pohdimme, mitä Eurooppaa kohdannut niin kutsuttu pakolaiskriisi on Suomessa merkinnyt vastaanottokeskusten ammatillisuudelle erityisesti koskien keskusten sosiaalihuoltoa ja sosiaalityötä. Pyrimme luomaan kuvaa niistä haasteista, joita järjestelmä on kohdannut sekä paikantamaan millaista sosiaalityön asiantuntijuutta se tarvitsee. Kirjoitus pohjautuu vastaanottokeskusten sosiaalityöntekijöinä asiakastyössä tekemiimme havaintoihin. Asiakkaat voivat hakemuksensa käsittelyä odottaessaan majoittua useissa keskuksissa, joten heidän tilanteisiinsa tutustuminen on mahdollistanut laajemman kuvan luomisen vastaanottokeskusten toiminnasta ja asiakkaiden asemasta paitsi keskuksissa, myös kunnissa, joissa keskuksia sijaitsee. Koska vastaanottojärjestelmä elää murrosvaihetta, tulee puheenvuoromme ymmärtää katsauksena poikkeukselliseen tilanteeseen ja toiveena tulevan suhteen. Haluamme kuitenkin pitää avoimena myös sen mahdollisuuden, että kuvaamamme ongelmat ovat olleet osa järjestelmää jo aiemmin, ja että murrosvaihe on luonut valoa niihin rakenteisiin, joissa turvapaikkaa hakeva kohtaa suomalaisen vastaanottojärjestelmän.

Käytämme tässä puheenvuorossa ilmaisua turvapaikkaa hakeva korostaak- semme kansainvälisen suojelun hakemista tekona. Haluamme vastustaa sellaista negatiivisia stereotypioita sisältävää turvapaikanhakijuntta, jossa se ymmärretään yksilöä määrittävänä tekijänä. Turvapaikkaa hakevia voidaan pitää tietoisesti ja pysyväisluontoisesti marginalisoituina rajallisten oikeuksien haltijoina. Tämä tarkoittaa, että heidän ihmisoikeutensa toteutuvat väistämättä rajoitettuina. (Rautiainen 2016, 35.) Hyvinvointivaltion käytännöissä ihmisoikeudet ovat vahvasti valtiokansalaisuuteen kiinnittyneitä, sillä universalismi käsittää periaatteessa ainoastaan omat kansalaiset ja maassa tietyn ajan asuneet. (Ranta-Tyrkkö 2017, 273, 282-283; Sipilä \& Anttonen 2016, 55.) Puheenvuoromme lähtökohta on, että paetessaan ihmisoikeusloukkauksia turvapaikkaa hakevat voivat olla tilanteessa, jossa myös vastaanottava valtio kieltää heiltä ihmisoikeudet (Turtiainen 2017, 197-99, 202-203). Esittelemme havaintojamme siitä, millaisia haasteita vastaanottokeskuksissa on sosiaalipalveluiden näkökulmasta. Huolenaiheemme koskevat ennen kaikkea sosiaalityön asiantuntijuuden puutteita ja asiakkaiden oikeuksien tarpeetonta rajoittamista.

Yhteiskunnallisella tasolla puheenvuoromme kiinnittyy keskusteluun sosiaalityön ammatillisuuden murrosvaiheesta tilanteessa, jossa sosiaalinen jää 
talouden varjoon. Vastaanottokeskuksissa tehtävä työ on sidoksissa paitsi vallalla olevaan uusliberalistiseen yhteiskuntapolitiikkaan, myös pakkomuuton kaltaisen globaalin ongelman ratkaisutarpeisiin lokaalisina kysymyksinä. Meneillään olevat kehityskulut ovat monin tavoin sosiaalityön toimintaympäristöä ja arvoperustaa horjuttavia, asettaen haasteita myös sosiaalityöntekijöiden ammatti-identiteetille ja toimintarooleille. (Lindh ym. 2018, 42, 48; Pohjola 2018.) Tässä puheenvuorossa sosiaalipalveluilla viitataan vastaanottolain mukaisiin sosiaalipalveluihin, kun taas sosiaalihuolto viittaa kaikkeen sosiaalihuoltolain mukaiseen työhön.

\section{VASTAANOTTOKESKUKSEN} SOSIAALIPALVELUT JA NIIDEN JOHTAMINEN

Vastaanottotoiminta on "ennen kaikkea moniviranomaistoimintaa sekä sosiaali- ja terveydenhuollon osaamista ja koulutusta vaativaa ammatillista työtä, jossa noudatetaan vastaanottolain lisäksi sosiaali- ja terveyssektorin lainsäädäntöä” (HE 131/2016). Keskusten toiminnasta vastaavilta johtajilta edellytetään kuitenkin vain "tehtävään soveltuvaa tutkintoa, hyvää perehtyneisyyttä virkaan kuuluviin tehtäviin, käytännössä osoitettua johtamistaitoa ja tehtävän edellyttämää vieraan kielen taitoa" (Vastaanottolaki 10\$). Vastaanottotoiminnan ohjaus, suunnittelu ja valvonta kuuluvat Maahanmuuttovirastolle (Vastaanottolaki 8§).Tämä koskee myös sosiaalipalveluita. Siinä, missä kaikkea muuta sosiaalihuoltoa valvovat aluehallintovirastot, Valvira sekä sosiaali- ja terveysministeriö (Valkonen 2016, 170, 175), vastaanottokeskusten sosiaalipalveluita valvoo Maahanmuuttovirasto.
Valvontaraportissaan (2017) Maahanmuuttovirasto toteaa, että vastaanottokeskustoiminnassa onnistuminen edellyttää "kohtuullista kokemusta käytännön työstä". Vuonna 2015 perustetuissa keskuksissa ei yksittäisillä työntekijöillä eikä toimijoilla laajemminkaan ole kuitenkaan ollut juuri aiempaa kokemusta toiminnasta. (Maahanmuuttovirasto 2017.) Kentälle on siis kerralla tullut useita toimijoita, joilla ei ole ollut edes perustietoja tuottamansa palvelun toimintakentästä.

Keskusten ohjaustyössä on työskennelty värikkäillä koulutustaustoilla, eikä edes sosiaalihuollon tehtäviin ole kaikissa keskuksissa edellytetty ammattihenkilölain mukaista pätevyyttä. Paikoitellen sosiaalipalvelut ovat pyörineet kokonaan sosiaaliohjaajien työpanoksella (esim. HS 8.3.2018).

Olemme toisinaan kuvanneet vastaanottokeskusta vertaamalla sitä asiakkaiden kotikuntaan: asiakkaat saavat välttämättömät sosiaali- ja terveydenhuollon palvelunsa vastaanottokeskuksesta tai sen kautta. Kansainvälistä suojelua hakevalla on oikeus saada sosiaalihuollon ammattihenkilön välttämättömäksi katsomia sosiaalihuoltolain 14. §:n mukaisia palveluita. Tämän lisäksi vastaanottokeskus vastaa asiakkaidensa välttämättömästä toimeentulosta. Keskuksen työntekijä toimii viranomaisena arvioidessaan palveluiden ja etuuksien tarvetta tai tehdessään niistä hallintopäätöksiä. Vaatimukset oikeusturvasta ja hyvästä hallinnosta koskevat vastaanottotoimintaa, ja hallinnollisia päätöksiä tehdessään päätöksentekijät toimivat aina virkavastuulla (Vastaanottolaki 10\$, kts. myös Arajärvi 2016, 75). Tuen tarpeisiin vastaavan työskentelyn 
lisäksi vastaanottokeskuksen sosiaalialan ammattihenkilöt ohjaavat ja neuvovat asiakkaita turvapaikkaa koskevan hakemuksen käsittelyyn sekä esimerkiksi työntekoon ja asumiseen liittyvissä kysymyksissä. Kokemuksemme mukaan jälkimmäisillä tehtävillä on taipumus korostua sosiaalihuoltolain mukaisen työskentelyn kustannuksella jopa siinä märin, että joissain keskuksissa ne itsessään ymmärretään koko sosiaalipalveluiden kokonaisuudeksi.

Maahanmuuttovirasto on ohjannut vastaanottokeskusten toimintaa ja palveluita antamalla niitä koskevia melko yksityiskohtaisia ohjeita. Niissä ohjeistetaan sellaisia perustavanlaatuista ammattitaitoa vaativia asioita $\mathrm{ku}-$ ten vastaanottorahan myöntäminen tai asiantuntijalausuntojen antaminen. Vastaanottokeskusten arkea on kokemuksemme mukaan monessa kohdin johdettu nimenomaan nojaten näihin ohjeisiin keskuksissa toimivia ammattiryhmiä määrittävän substanssikohtaisen ammattitaidon ja -etiikan sijaan. Tiina Sotkasiiran (tässä numerossa) haastattelemat vastaanottokeskuksen johtajat näkivätkin itsensä ensisijaisesti Maahanmuuttoviraston hallintoalamaisina ja vetosivat johtamisessaan virastolta saatuihin ohjeisiin. Lisäksi vastaanottokeskusten sisällä johtajat pitivät asemaansa lähes rikkomattomana. Sotkasiira toteaa, että vastaanottotyötä ammatikseen tekevien puheessa painottui sellainen moderni asiantuntijuus, jossa hyvän elämän tavoitteet on mahdollista määritellä ulkopuolelta käsin. Siihen kuuluu olettamus auktoriteettien kunnioittamisesta, jakamattomasta yhtenäiskulttuurista sekä eurooppalaisen kulttuurin ylivertaisuudesta. Tässä asetelmassa turvapaikkaa hakeva määrittyi hierarkki- sesti alemmaksi, ammattilaisten hallinnan kohteiksi. (Mt.) Tällainen ylivallan ketjuuntuminen voi vastaanottotyössä tuntua luontevalta. Työntekijällä on valtaa suhteessa asiakkaaseen, esimiehellä työntekijään, johdolla esimiehiin, toimintaympäristöllä organisaatioon ja niin edelleen. Ylivallan oleellisena taipumuksena onkin saavuttaa legitiimi asema. (Hokkanen 2013, 63.)

Katsomme ohjeilla johtamisen edustavan niin kutsuttua uutta julkisjohtamista, New Public Managementia, joka Kirsi Juhilan (2011) mukaan tuo vahvan budjettikontrollin toimintojen suunnitteluun. Samalla kun organisaation asema vahvistuu, työntekijöiden liikkumavara professionsa pohjalta kapenee. Työntekijöistä tulee palvelujen tai etuuksien saamisen portinvartijoita. (mt., 54.) Sosiaalihuollossa työntekijä toimii perustuslaissa ja sosiaalihuoltolaissa säädettyjen velvollisuuksien toimeenpanijana, mutta on saattanut joutua tinkimään asiakkaan oikeuksista ja edusta toimiakseen ohjeistusten puitteissa. (Sipilä 2011, 146-147.) Tämä on entisestään korostunut etenkin silloin, kun vastaanottokeskusten sosiaalipalveluissa toimivilta ei ole edellytetty asianmukaista koulutusta.

Ohjeilla johtamisen kannalta keskeinen kysymys onkin liittynyt substanssiosaamisen puutteeseen, sillä ammattilaisille suunnattuihin ohjeisiin on kirjoitettu sisään asiantuntijuuden pohjalta tehdyn ammatillisen harkinnan mahdollisuus. Koska Maahanmuuttovirasto vahtii vastaanottokeskusten taloudenhallintaa osana valvontatehtäväänsä, on johto voinut vahtia esimerkiksi vastaanottorahapäätöksiä tai sosiaalipalveluiden myöntämistä suhteessa annettuihin 
ohjeisiin. Tuolloin sosiaalityön ulkopuolelta on ammattilaisten käyttöön annettuja ohjeita tulkitsemalla määritetty, minkälaisia päätöksiä sosiaalihuollossa voidaan tehdä, vaikka laissa sosiaalihuollon ammattihenkilöistä (817/2015) sosiaalityön ammatillinen johtaminen säädetään sosiaalityöntekijän erityiseksi velvollisuudeksi.

Näyttääkin siltä, että vastanottokeskuksissa ammattitaito on paikoitellen kokonaan korvattu ohjeilla. Ammatillisessa auttamistyössä ei kuitenkaan riitä asiakkaan elämäntilanteen sijoittaminen valmiiseen lokeroon, vaan siinä vaaditaan kuvailua kehittyneempää erittelyä tilanteesta. Professionaalinen auttaminen on kaavamaisuutta ja määrämuotoisuutta kaihtavaa erityistä käytäntöä, johon liittyy teknisten kysymysten rajat ylittävää abstraktin tiedon käyttöönottoa. Sosiaalityössä yksilöllinen subjekti käsitetään suhteessa yleiseen, eikä toimenpiteitä siksi voida käytännössä toteuttaa määrämuotoisesti. (Rostila \& Vinnurva 2013, 198, 205.) Katsommekin, että sosiaalityön asiantuntijuuden puuttuminen on altistanut koko vastaanottojärjestelmän juuri sellaisille tulkinnoille, joissa korostuvat etuuksien tai palveluiden kaavamainen myöntäminen yksilöllisen harkinnan ja tarpeen sijaan. Tilanne on merkinnyt asiakkaiden oikeuksien rajaamista mahdollisimman kapeiksi ja taloudellisesti edullisiksi. Tämän mahdollistaa tilanne, jossa asiakas nähdään vain toimenpiteiden kohteena tai hänen katsotaan yrittävän keinotella etuuksia itselleen (Pohjola 2006, 43-49). Sosiaalihuoltoon kuuluvan kontrollin, vallankäytön ja organisaatioiden toimintatapoihin liittyvien ristiriitojen tunnustaminen ja käsittely ovat sosiaalityöntekijän am- matillisuuden ydintä (Sipilä 2011, $146-$ 147). Tästä syystä ei ole yhdentekevää, millä koulutuksella ja osaamisella sosiaalihuollon työtä tehdään.

Vastaanottokeskuksen sosiaalipalvelut kytkeytyvät tiiviisti myös asiakkaiden oikeusturvan kysymyksiin, sillä monenlaisten tuen tarpeiden tunnistaminen voi olla avainasemassa oleskelulupaa koskevan hakemuksen käsittelyssä. Sosiaalihuollossa erityisen tuen tarpeessa olevan asiakkaan palvelutarpeen arvioista vastaa sosiaalityöntekijä. Vastaanottopalveluissa erityisen tuen tarve on yhteydessä myös vastaanottolain mukaisen haavoittuvan aseman tunnistamiseen. Sosiaalityön ammattilaisten puute on ollut erityisen ongelmallista juuri erityisen tuen tarpeessa olevien asiakkaiden kohdalla, sillä heidän palvelutarvettaan ei ole ollut arvioimassa pätevää henkilökuntaa. Erityisen tuen tarpeessa olevia ei siis ikään kuin ole ollut, koska keskuksissa ei ole ollut heidän tunnistamiseen riittävän ammattitaidon omaavaa henkilökuntaa. Tuolloin myös heidän haavoittuva asemansa on saattanut jäädä tunnistamatta oleskelulupaa koskevan hakemuksen käsittelyssä. Asiakkaiden oikeus laadukkaaseen sosiaalihuoltoon ei ole toteutunut yhdenvertaisesti, vaan ollut riippuvainen siitä, missä keskuksessa asiakas on sattunut majoittumaan ja minkälaista osaamista keskuksen johto on sosiaalihuollossa toimivilta vaatinut.

Sosiaalihuollon oikeussuoja- ja valvontajärjestelmän on tarkoitus turvata, että asiakkaat saavat tarpeelliset ja riittävät palvelut ja etuudet, eikä heidän itsemäräämisoikeuttaan rajoiteta muutoin kuin lain suomin edellytyksin (Valkonen 2016, 171). Järjestelmä näyttää 
laajemmin turvapaikkaa hakevien, mutta varsinkin erityisen tuen tarpeessa olevien kohdalla pettäneen, kun keskuksia ei ole edellytetty palkkaamaan sosiaalityöntekijöitä. Onkin paikallaan pohtia, onko Maahanmuuttovirasto oikea taho valvomaan ja ohjeistamaan sosiaalihuollon toimintaa. Lisäksi tulisi pohtia, miten turvapaikanhakijoiden oikeusturva toteutuu, kun sama taho sekä ostaa, ohjeistaa ja valvoo vastaanottopalveluita että tekee asiakkaiden oleskelulupaa koskevat päätökset, joihin näiden palveluiden myöntäminen saattaa vaikuttaa.

\section{Miksi VASTAANOTTOKESKUKSISSA SITTEN TARVITAAN SOSIAALITYÖN OSAAMISTA?}

Kysymys asiantuntijuudesta muodostuu erityisen olennaiseksi, kun lähtökohdaksi ymmärretään, että sosiaalityön ytimessä on toimintavallan käyttäminen. Asiakassuhteessa työntekijän positiivinen vallankäyttö liittyy hänen mahdollisuuksiinsa poistaa asiakkaassa voimattomuutta aiheuttavia tekijöitä. (Hokkanen 2013, 64.) Vastaavasti negatiivista vallankäyttöä on yleisesti ottaen hyvän elämän edellytyksiä kaventava vallankäyttö, joka liittyy yksilön elämän perusteettomaan kontrolloimiseen, heidän esineellistämiseensä tai mitätöimiseensä. Valtarakenteet voivat säädellä asiakkaan roolia paitsi mahdollistaen, myös rajoittaen osallisuuden muotoja ja mahdollisuuksia. Asiakkaiden toimijuuteen ja osallisuuteen kietoutuu väistämättä valta siitäkin huolimatta, etteivät sitä harjoittavat ihmiset tunnistaisi sen kaikkia ulottuvuuksia (Niemi 2013, 31-33, 44.) Myös hyvää tarkoittava puolesta tekeminen voi kääntyä negatiiviseksi vallankäytöksi silloin, kun sen kautta kielletään yksilön oma toimijuus. Turvapaikkaa hakevia on esimerkiksi voitu auttaa avuttomiksi tekemällä heidän puolestaan asioita tai olettamalla, etteivät he kykene itsenäiseen toimintaan. Näin yksilölle on auttamissuhteessa tarjottu ulkopuolelta vain roolia toimenpiteiden tai määrittelyiden kohteena. Sosiaalityön ammattilaisen tehtäväksi rakentuukin toimiminen neutraalina ongelmatilanteita jäsentävänä asiantuntijana, jolla on kykyä reflektiiviseen ajatteluun ja työn arviointiin. (Sipilä 2011, 13, 139, 149).

Sosiaalityön asiantuntijan osaaminen kiinnittyy vastaanottopalveluissa paitsi sosiaalipalveluihin myös esimerkiksi majoitukseen ja sellaisiin asioihin kuin yksityisyyden ja perhe-elämän suoja. Keskuksissa on ollut tapana ratkaista haasteellisesti käyttäytyvän asiakkaan tilanne siirtämällä asiakas toiseen keskukseen. Vastaanottokeskussiirtoja on käytetty joissakin keskuksissa rangaistuskeinoina sen sijaan, että asiakkaan tilannetta olisi lähdetty selvittämään ja tarjottu tukea sekä mahdollisuutta tulla kuulluksi ja kohdatuksi. Myös esimerkiksi perheväkivaltaepäilyn johdosta perheenjäseniä on erotettu toisistaan vastoin heidän tahtoaan. Siirtoja on toisinaan edellytetty kunnan lastensuojelusta. Vastaanottokeskushenkilökunnan on näissä tilanteissa ollut ilmeisen vaikeaa tunnistaa oman toimintansa velvollisuuksia kunnan viranomaisen sanellessa toimenpiteitä. Lastensuojelu ei voi edellyttää vastaanottokeskuksia siirtämään perheenjäseniä eri keskuksiin, vaikka se käytännössä olisikin mahdollista tai jopa näennäisen helppo tapa ratkaista ongelmia. Näissä tilanteissa asiakkailla ei myöskään ole ollut mahdollisuutta 
vaikuttaa ratkaisuun tai hakea siihen muutosta. Pohdittavaksi jää lisäksi, miten lapsen oikeus suojeluun on toteutunut, jos lastensuojelun mahdollinen palveluntarve on ohitettu siirtämällä epäilty väkivallantekijä toiseen keskukseen.

Muun muassa tällä tavoin keskuksissa on puututtu asiakkaiden perustuslain ja ihmisoikeussopimusten takaamiin oikeuksiin sekä laiminlyöty hyvä hallinto ja asiakkaan oikeus laadukkaaseen sosiaalipalveluun. Vastaanottojärjestelmään on luotu erilaisin vallankäytön välinein hyvinvointivaltion rinnakkaistodellisuus, jossa turvapaikkaa hakevat eivät pahimmillaan tule kohdelluiksi yhteiskunnassa muutoin vallitsevien sääntöjen ja käytäntöjen mukaisesti.

\section{Miten TÄSTÄ ETEENPÄIN?}

Olemme edellä kuvanneet vastaanottotoiminnan järjestämiseen liittyviä huolenaiheitamme. Katsomme, että vastaanottopalveluissa asiantuntijuuden ja ammatillisuuden laiminlyönti on ollut järjestelmän rakenteellinen ongelma, joka on vaikuttanut asiakkaiden saamien palveluiden laatuun ja sitä kautta heidän hyvinvointiinsa. Pahimmillaan se on vaikuttanut turvapaikkaa hakevien kohteluun vastaanottopalveluissa ja lopulta heidän oikeuteensa saada kansainvälistä suojelua koskeva hakemus asianmukaisesti käsitellyksi.

Sosiaalityön asiantuntijuutta ei voida korvata ohjeista lukemalla, eikä se saa olla alisteista sosiaalityön ulkopuolelta tehdyille määrittelyille. Tästä syystä vastaanottopalveluiden sosiaalityöntekijän oleelliseksi perustehtäväksi tulee ymmärtää nykyjärjestelmässä myös sosiaalinen asianajo. Tarkoitamme tällä sellaista sosiaalityön orientaatiota, jossa muutetaan asiakkaan tilanteelle relevanttia järjestelmää, toimintakäytäntöjä ja rakenteita. Asianajon tarve nousee paitsi sen palvelujärjestelmän toiminnasta, jossa sosiaalityöntekijä toimii, myös asiakaskunnan sijoittumisesta hyvinvointiyhteiskunnan auttamiskontekstin ulkopuolelle. Asianajo kumpuaa sosiaalityön ihmiskäsityksestä, maailmankuvasta ja eettisistä lähtökohdista. Siinä korostuu sosiaalityöntekijän toimijuus suhteessa rakenteeseen, vaikka asiakas elämäntilanteineen ohjaakin prosessia. (Hokkanen 2013, 74-79.) Vastaanottopalveluissa asiakaskohtainen asianajo on oikeuksien toteutumisen sekä etuuksien ja palvelujen saamisen tarkistamista myös suhteessa kunnallisiin sosiaalipalveluihin. Tuolloin sosiaalityön keskeinen ydintehtävä on asiakkaan oikeuksista kiinni pitäminen ja heidän asioidensa ajaminen. Koska asiakkaiden kohtaamista raamittavat laajemmat yhteiskunnalliset kehykset, liittyy sosiaalityön arvo-osaaminen paitsi kykyyn reagoida tilanteisiin, myös organisatoristen rakenteiden ja ehtojen sekä asiakassuhteen niveltämiseen toisiinsa. (Laitinen \& Kemppainen 2010, 138-140.) Sosiaalityössä on tunnistettava, että nopeasti muuttuvassa maailmassa yhteiskuntien tulevaisuutta koskevassa kampailussa haavoittuvimpien puolustaminen edellyttää vahvasti poliittista ja rakenteellista työotetta. Saadakseen aikaan muutosta työntekijän tulee käyttää sitä valtaa, joka hänellä on käyttöönotettavissaan ammattistatuksensa kautta. (Hokkanen 2013, 76-77.) 


\section{LoPUKSI}

Kansainvälistä suojelua hakevien kanssa tehtävän työn keskeisin tasapainottelu liittyy parhaimmillaan asiakkaiden itsenäisen selviytymisen tukemisen ja auttamisen välisen hiuksenhienon tasapainon löytämiseen. Työn lähtökohtana on aina pidettävä sitä, että osa turvapaikkaa hakevien toimintakyvyn tai jaksamisen ongelmista on normaaleja reaktioita epänormaaliin tilanteeseen. Monille riittää tueksi se, että heitä kohdellaan asiallisesti, oikeudenmukaisesti, ja että joku sanoittaa tilannetta heille. Toisaalta asiakaskunnassa on myös vaikeasti traumatisoituneita ja toimintakyvyltään merkittävästi alentuneita henkilöitä. Sosiaalityön ammattilaisen asiantuntijuutta tarvitaan erottamaan nämä toisistaan. Tuki, auttaminen ja kannustaminen itsenäiseen selviytymiseen on sovitettava kunkin asiakkaan yksilölliseen tilanteeseen.

Ennen kaikkea vastaanottokeskustyössä korostuu asiakkaan toimijuuden ja sosiaalisten ihmisoikeuksien kunnioittaminen sekä asiakkaiden näkeminen oman elämänsä subjekteina. Sosiaalityöntekijä tuo näihin kysymyksiin oleellisesti kuuluvan asiantuntijuuden keskuksen henkilöstöön. Vastaanottokeskustoiminnassa ei riitä pelkkää ohjeiden mukainen suorittaminen, vaan ammatillisen toiminnan on perustuttava koulutuksen kautta saatuun ammattitaitoon ja ammattietiikan syvälliseen ymmärtämiseen. Sosiaalisten ihmisoikeuksien näkökulmasta yhdenvertaisuutta tulee edistää erityisesti poistamalla näkymätöntä rakenteellista syrjintää, joka ilmenee esimerkiksi ammattihenkilöiden koulutusvaatimusten laiminlyönnissä valvovan viranomaisen taholta. Jos sosiaalisten ihmisoikeuksien toteutumista joutuu vaatimaan viranomaisprosessissa, ihmisoikeudet eivät oikeastaan toteudu (Rautiainen 2016, 22-25; 35). Koska ulossulkeva nationalismi on pakkomuuttajien oikeuksien esteenä, tulee heidän kanssaan tehtävän sosiaalityön perustavanlaatuiseksi tehtäväksi ymmärtää nationalististen käytäntöjen tunnistaminen ja purkaminen toimintaympäristössään (Turtiainen 2017, 205-206; 213-214). Sosiaalityöntekijöiden tehtäväksi nousee tuolloin olla ihmisoikeuksien ja ammattietiikan perälauta, rakenteellisen eriarvoisuuden ja yksilöiden oikeudenmukaisen kohtelun välisen suhteen riippumaton asiantuntija.

\section{Kirjallisuus}

Arajärvi, Pentti (2016) Sosiaaliturvan perustuslaillisia näkökohtia. Teoksessa Eeva Nykänen, Laura Kalliomaa-Puha \& Yrjö Mattila (toim.) Sosiaaliset oikeudet - näkökulmia perustaan ja toteutumiseen. Helsinki: Terveyden ja hyvinvoinnin laitos, 69-84.

Hokkanen, Liisa (2013) Asiakaskansalaisen toimijuus sosiaalityöllisessä asianajossa. Teoksessa Merja Laitinen \& Asta Niskala (toim.) Asiakkaat toimijoina sosiaalityössä. Tampere:Vastapaino, 55-86.

Hallituksen esitys eduskunnalle laeiksi Maahanmuuttovirastosta annetun lain 2 §:n ja kansainvälistä suojelua hakevan vastaanotosta sekä ihmiskaupan uhrin tunnistamisesta ja auttamisesta annetun lain 9 ja 10 \$:n muuttamisesta. HE 131/2016 https://www.finlex.fi/fi/ esitykset/he/2016/20160131 luettu 10.5.2018.

Helsingin Sanomat 24.10.2017 https:// www.hs.fi/talous/art-2000005420389. html luettu 10.5.2018.

Helsingin Sanomat 8.2.2018 https://www. hs.fi/kotimaa/art-2000005595658.html luettu 4.9.2018. 
Hämäläinen, Juha (2015) Tiedontuotanto sosiaalityön rakenteellisena kysymyksenä. Teoksessa

Anneli Pohjola, Merja Laitinen \& Marjaana Seppänen (toim.) Rakenteellinen sosiaalityö. Kuopio: Unipress, 64-86.

Juhila Kirsi (2006) Sosiaalityöntekijöinä ja asiakkaina. Sosiaalityön yhteiskunnalliset tehtävät ja paikat. Tampere:Vastapaino.

Kaisto, Jani \& Pyykkönen, Miikka (2010) Hallinnan analytiikan suuntaviivoja. Teoksessa Jani Kaisto \& Miikka Pyykkönen (toim.) Hallintavalta. Sosiaalisen, politiikan ja talouden kysymyksiä. Tampere: Gaudeamus, 7-26.

Kivipelto, Minna (2004) Sosiaalityön kriittinen arviointi sukupuolistavien merkitysten ja käytäntöjen purkajana. Teoksessa Marjo Kuronen, Riitta Granfelt, Leo Nyqvist \& Päivi Petrelius (toim.) Sukupuoli ja sosiaalityö. Jyväskylä: PS-Kustannus, 249-276.

Laitinen, Merja \& Kemppainen, Tarja (2010) Asiakkaan arvokas kohtaaminen. Teoksessa Merja Laitinen \& Anneli Pohjola (toim.) Asiakkuus sosiaalityössä. Tampere: Gaudeamus, 138-180.

Laki kansainvälistä suojelua hakevan vastaanotosta sekä ihmiskaupan uhrin tunnistamisesta ja auttamisesta 17.6.2011/746, nk. "vastaanottolaki".

Laki sosiaalihuollon ammattihenkilöistä $817 / 2015$.

Lindh, Jari \& Hautala, Sanna \& Romakkaniemi, Marjo (2018) Sosiaalityön asiantuntijuus heikoimmassa asemassa olevien kanssa tehtävässä työssä. Teoksessa Tarja Juvonen, Jari Lindh, Anneli Pohjola \& Marjo Romakkaniemi (toim.) Sosiaalityön muuttuva asiantuntijuus. Sosiaalityön tutkimuksen vuosikirja 2018. Kuopio: UNIPress, 39-65.

Maahanmuuttovirasto (2017). Vastaanottojärjestelmän valvontaraportti 1.1.2016-30.4.2017. https://migri.fi/ documents/10197/5798793/74270_ Vastaanottojarjestelman_valvontaraportti_1.1.2016-30.pdf luettu 4.5.2018

Niemi, Petteri (2013) Hyvä, paha valta. Teoksessa Merja Laitinen \& Asta Niskala (toim.) Asiakkaat toimijoina sosiaalityössä. Tampere:Vastapaino, 31-54.

Palola, Elina, Rintala, Taina \& Savio, Annikki (2010) Elämää kumppanuusvaltiossa.
Teoksessa Sakari Hänninen, Elina Palola \& Maija Kaivonurmi (toim.) Mikä meitä jakaa? Sosiaalipolitiikkaa kilpailuvaltiossa. Terveyden ja hyvinvoinnin laitos. Helsinki:Yliopistopaino, 53-82.

Pehkonen, Aini \& Väänänen-Fomin Marja (2011) Arvojen ja etiikan dilemma sosiaalityössä. Teoksessa Aini Pehkonen \& Marja Väänänen-Fomin (toim.) Sosiaalityön arvot ja etiikka. Jyväskylä: PS-Kustannus, 7-12.

Petrelius, Päivi (2005) Sukupuoli ja subjektius sosiaalityössä. Jyväskylä: Jyväskylän yliopisto

Pohjola, Anneli (2006) Pahan säikeitä auttamistyössä. Teoksessa Merja Laitinen \& Johanna Hurtig (toim.) Pahan kosketus. Ihmisyyden ja auttamistyön varjojen jäljillä. Jyväskylä: PS-kustannus, 42-62.

Pohjola, Anneli (2015) Rakenteellisen sosiaalityön paikannuksia. Teoksessa Anneli Pohjola \& Merja Laitinen \& Marjaana Seppänen (toim.) Rakenteellinen sosiaalityö. Kuopio: Unipress, 16-36.

Pohjola, Anneli (2018) Sosiaalityön muuttuvan asiantuntijuuden ydintekijöitä. Teoksessa Tarja Juvonen, Jari Lindh, Anneli Pohjola \& Marjo Romakkaniemi (toim.) Sosiaalityön muuttuva asiantuntijuus. Sosiaalityön tutkimuksen vuosikirja 2018. Kuopio: Unipress, 280-292.

Ranta-Tyrkkö, Satu (2017) Ihmisoikeudet ja sosiaalityö globaalien kriisien maailmassa. Teoksessa Maija Jäppinen, Anna Metteri, Satu Ranta-Tyrkkö \& PirkkoLiisa Rauhala (toim.) Kansainvälinen sosiaalityö - käsitteitä, käytäntöjä ja kehityskulkuja. Kuopio: Unipress, 273-300.

Rautiainen, Pauli (2016) Sosiaaliset oikeudet ihmisoikeuksina. Teoksessa Eeva Nykänen, Laura Kalliomaa-Puha \& Yrjö Mattila (toim.) Sosiaaliset oikeudet - näkökulmia perustaan ja toteutumiseen. Helsinki: Terveyden ja hyvinvoinnin laitos, 23-39.

Rose, Stephen M. (2003) Sosiaalityön missio. Teoksessa Merja Laitinen \& Anneli Pohjola (toim.) Sosiaalisen vaihtuvat vastuut. Jyväskylä: PS-Kustannus, 193-205.

Rostila, Ilmari \& Vinnurva, Jukka (2013) Sosiaalityön asiakkaan toimijuus ja täysimittainen professionaalisuus. Teoksessa Merja Laitinen \& Asta Niskala (toim.) Asiakkaat toimijoina sosiaalityössä. Tam- 
pere:Vastapaino, 196-218.

Sipilä, Anita (2011) Sosiaalityön asiantuntijuuden ulottuvuudet - tiedot, taidot ja etiikka työntekijöiden näkökulmasta kunnallisessa sosiaalityössä. Itä-Suomen yliopisto. Yhteiskuntatieteiden ja kauppatieteiden tiedekunta. Publications of the University Of Eastern Finland. Dissertations in Social Sciences and Business Studies No 28. Kuopio: University of Eastern Finland.

Sipilä, Jorma \& Anttonen, Anneli (2016) Universalismi ja sen vaihtoehdot. Teoksessa Maritta Törrönen, Kaija Hänninen, Päivi Jouttimäki, Tiina Lehto-Lundén, Petra Salovaara \& Minna Veistilä (toim.) Vastavuoroinen sosiaalityö. Helsinki: Gaudeamus Helsinki University Press, 53-71.
Turtiainen, Kati (2017) Pakkomuutto sosiaalityössä kohdattavana ilmiönä. Teoksessa Maija Jäppinen, Anna Metteri, Satu Ranta-Tyrkkö \& Pirkko-Liisa Rauhala (toim.) Kansainvälinen sosiaalityö - käsitteitä, käytäntöjä ja kehityskulkuja. Sosiaalityön tutkimuksen vuosikirja 2016. Kuopio: Unipress, 203-224.

Valkonen, Tanja (2016) Sosiaalihuollon oikeussuojajärjestelmä ja asiakkaan tosiasialliset oikeudensaantimahdollisuudet. Teoksessa Eeva Nykänen, Laura Kalliomaa-Puha \& Yrjö Mattila (toim.) Sosiaaliset oikeudet - näkökulmia perustaan ja toteutumiseen. Helsinki: Terveyden ja hyvinvoinnin laitos, 170-184. 